INTERNATIONAL DESIGN CONFERENCE - DESIGN 2018

https://doi.org/10.21278/idc.2018.0333

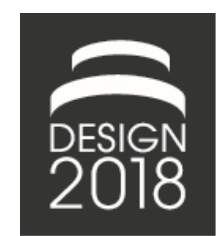

\title{
V-MODELS FOR INTERDISCIPLINARY SYSTEMS ENGINEERING
}

\author{
I. Graessler, J. Hentze and T. Bruckmann
}

\begin{abstract}
Changes in products, markets and technologies influence the development process and its approaches. The V-Model of the VDI 2206 from 2004 is an important basis for the industrial application of mechatronic product development. This paper shows which changes need to be integrated into the updated V-Model and in which areas the focused topics have to be changed to be prepared for future challenges. For this purpose, existing applied models are analyzed and the need for rework is elaborated.
\end{abstract}

Keywords: systems engineering (SE), new product development, design models

\section{Introduction}

Increasing complexity in product development, diverse specialization of workers and shorter time-tomarket are key drivers for industrial companies (Ehrlenspiel and Meerkamm, 2013). In order to meet these challenges, there is not only a need for changes in industrial practice, but also in the basic scientific methods that build the frameworks for product development processes.

The V-model, as published for software application by (Bröhl, 1995), has become one of the most important models for the development of technical systems in recent decades. The guideline of the VDI 2206 (VDI, 2004) from the year 2004 for the first time offered a comprehensive model for engineering mechatronic systems. Subsequently VDI 2206 was adapted in many ways by science and industry. Due to changes in technology, organisational and social environment, the V-model from 2004 needs to be updated to represent the state of the art of development processes (Gräßler et al., 2016).

To underline the necessities and point out the changes for a new release of the VDI 2206, the technical committee VDI GMA 4.10 "Interdisciplinary Product Creation" of the Association of German Engineers (VDI) was founded in March 2016. The committee aims at publishing a new version of the VDI 2206 guideline including an enhanced mechatronic V-model. This paper gives an overview of focal topics that emerge from the observed changes in technology and organisation as compared to the situation in 2004. Existing models with different interpretations and tailored approaches of the "V" are analysed and a resulting call for action for a renewed V-model is derived. The statements for enhancing the V-model are to be used as a basis for an intensive discussion inside and outside the technical committee VDI GMA 4.10.

\section{State-of-the-art: The mechatronic V-model}

The V-model of VDI guideline 2206:2004 (Figure 1) basically divides the development process into three sections: The decomposition on the left side of the V-model describes the transformation of requirements, which are presented as an input, into a system design. This leads to the second section of engineering in different disciplines, the domain-specific design process. The third section integrates the disciplines on the right side of the $\mathrm{V}$-model during the system integration, verification and validation. The result or output of the V-model is a product. The model is supplemented by a bracket for modelling 
and model analysis, which begins and ends at the middle height of the two sides. Arrows between the two sides of the V-model illustrate the assurance of properties comprising verification and validation activities. Note, the assurance of properties is indicated right-to-left, which gives the impression of a retrospective process (Gausemeier and Moehringer, 2003; VDI, 2004; Gräßler et al., 2016).

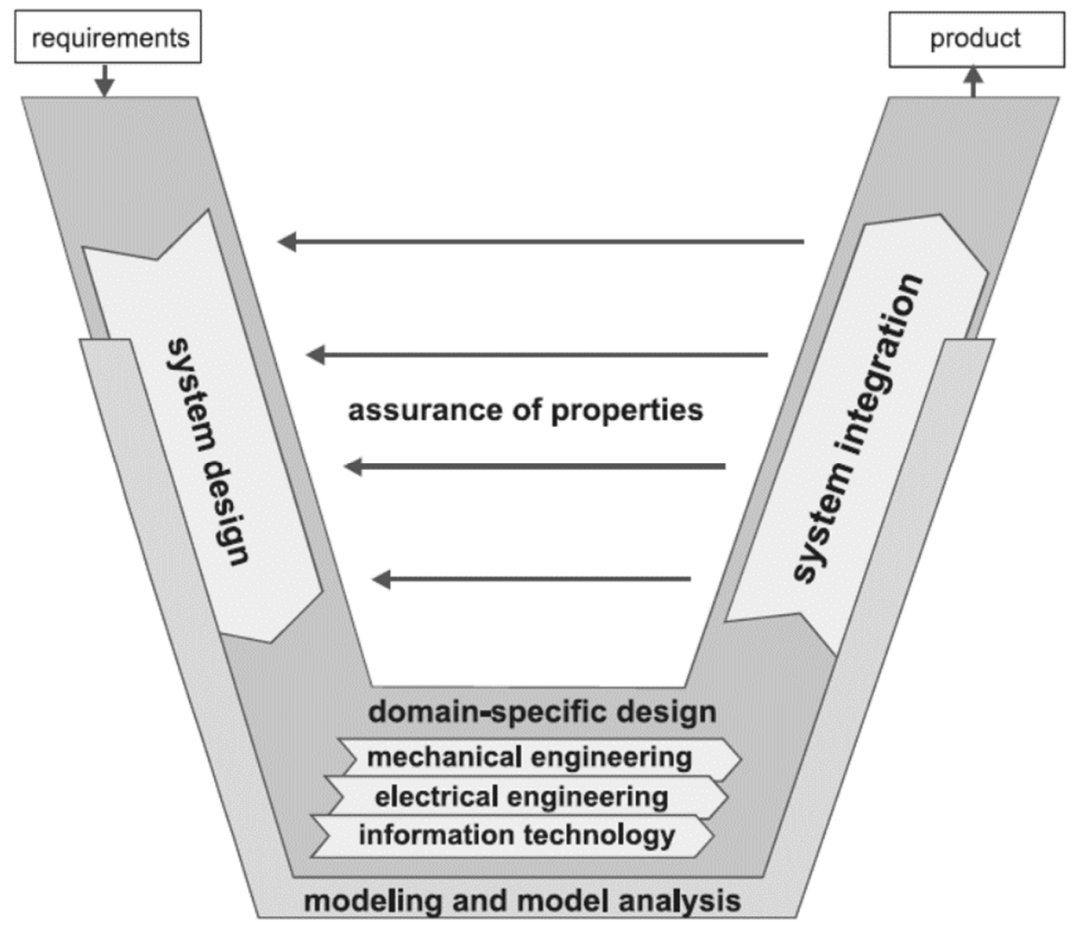

Figure 1. V-model of the VDI 2206:2004 guideline "Design methodology for mechatronic systems" (VDI, 2004)

\section{V-model variants and their interpretation}

In addition to the V-model of the VDI 2206 guideline, existing V-models are compared with each other, which are partly close to the basic model (Figure 3, Figure 4, Figure 5) and others that are specialized on specific branches of System Engineering (Figure 2, Figure 6). Improvement potentials are best identified by a selection of models as different as possible. Therefore out of the multitude of existing Vmodel-variations, those exemplary V-models were selected for the analysis of improvement potentials, which are as different as possible from each other and thus together represent a wide range of V-modelapplications. This way, the selected V-models comprise different characteristics and application fields of the classical V-model. Models from the overarching context of Systems Engineering (Walden et al., 2015) were considered as well as models dealing with specialized developments, such as microsystems technology (Watty, 2006). Through diversity of V-models, proven aspects in specific applications can be examined for general validity and, where appropriate, adopted to the general description. Further, all selected models are well established in their specific applications and frequently cited for scientific publications. For comparison of the six different interpretations of the V-model, eleven characteristic properties were identified to analyse the differences. These characteristic properties describe the models with regard to technological changes, market changes and the understanding and interpretation of the presented illustration. The characteristic properties are based on the motivation to enhance the V-model in the publications Gräßler and Hentze (2015), Gräßler et al. (2016) and Graessler (2017). All the eleven characteristic properties are explained by questions and answered qualitatively:

\section{Decomposition into System levels}

Q: Does the model refer to different system levels? Are there hints at decomposition of the system?

\section{Integration of model-based development approach}

Q: Are model-based approaches inherent to the process? Is this illustrated in the development model? 


\section{Provide status revision}

Q: Are there Check-ups, Feedback or status revisions, whether the approach is performed in a right manner?

4. Life cycle representation

Q: Does the approach refer to or include life cycle concepts?

5. Focused fields of application

Q: What is the field of application for the reference model? Are there special focuses or users?

6. Sequential or iterative approach

Q: Is the development process run in a sequential or iterative order? Does the model point out the possibility of iterations?

7. Adaptability to maturity levels

Q: Is the development approach applicable and understandable in all maturity levels of a product (e.g. virtual product, prototype, etc.)?

\section{Tutorial quality}

Q: How clear and understandable do the models convey the approach principle, especially to learners?

\section{Adaptability for domains}

Q: Is the approach adaptable to the different engineering disciplines or usable just for overall systems?

10. Consideration of Requirements Engineering

Q: How is the handling of requirements noted? Is a consistent process recognizable?

11. Verification and validation

Q: Is the assurance of properties represented as forward or backward process?

The V-model of the United States Department of Transportation (DoT) (U.S. Department of Transportation, 2009) guides through the Systems Engineering process for large and complex infrastructure systems, such as harbours, highways and railway lines. Striking properties are the straightforward approach, the differentiation of phases (time-based) and stages (content-based) and the introduction of decision gates. This $\mathrm{V}$-model draws attention to the different system levels. Furthermore, the model emphasizes the meaning of a careful preparation and definition of the verification process by arrows pointing from left to right. The V-form, with extended wings, is an established possibility for illustrating representation of the whole life cycle (Gräßler and Hentze, 2015). The extended V-model is shown in Figure 2.

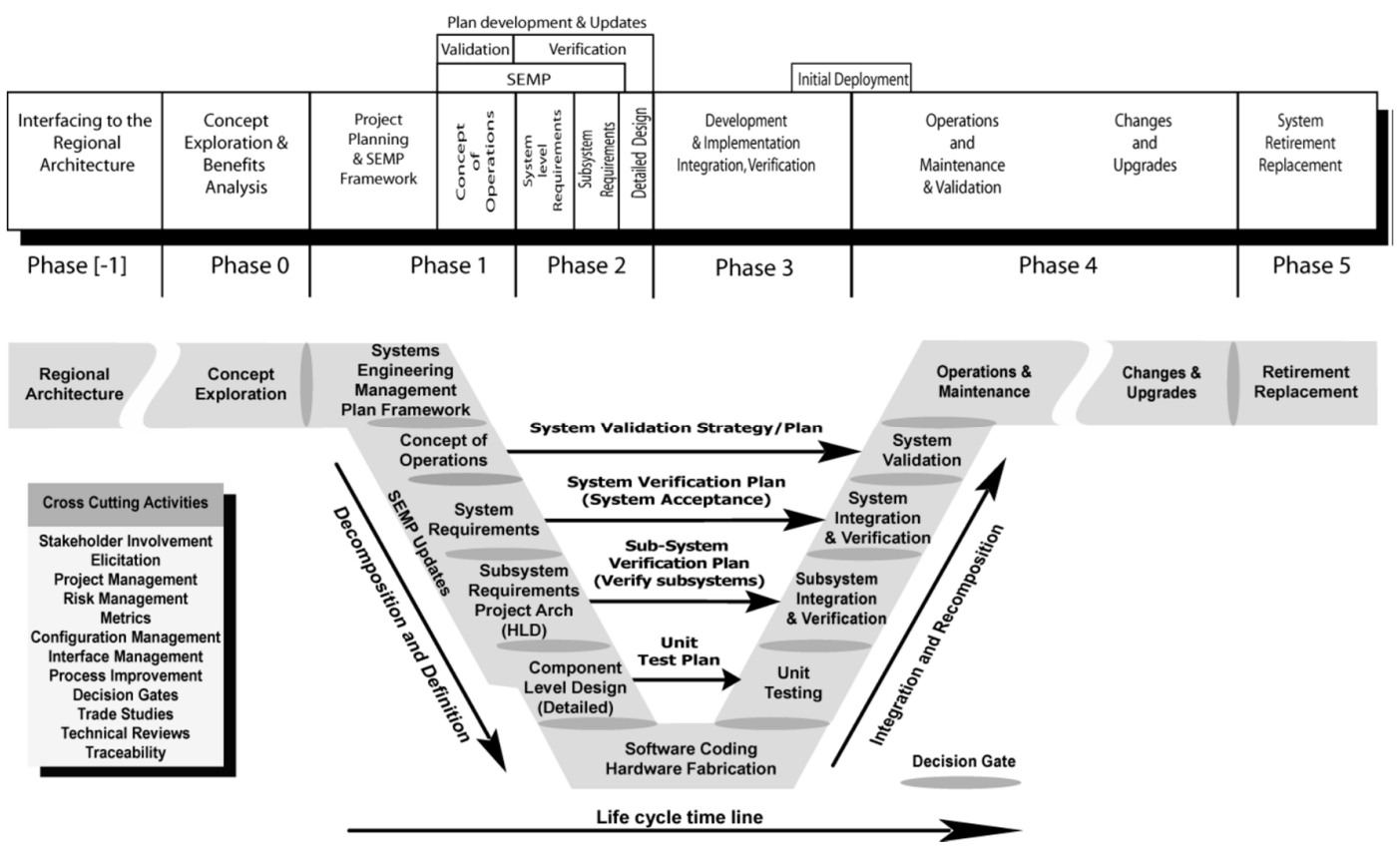

Figure 2. V-model of the US Department of Transportation (US-DoT) (U.S. Department of Transportation, 2009) 
Though the underlying structure of the V-model appears to be similar to the VDI 2206, the publication of Binz and Watty (Watty, 2006) changes the designation of different phases and illustrates the link to the product life cycle by eye-catching arrows (Figure 3). These give a schematic overview and do not represent a complete product life cycle model.

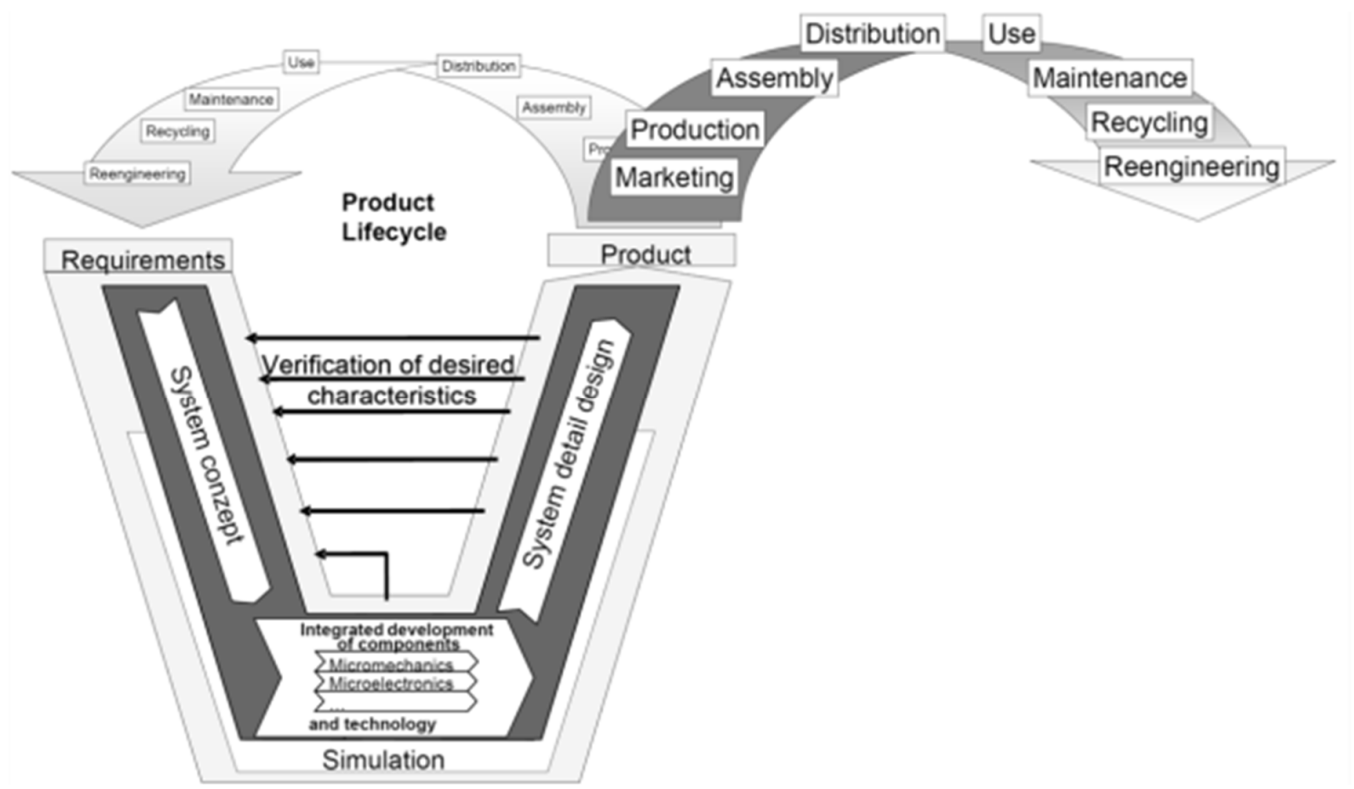

Figure 3. V-model for the development of microsystems technologies by Binz and Watty, (Watty, 2006)

Eigner combines the model for the approach in development with a virtual and data-based approach (Eigner et al., 2012). The integration of a PLM backbone and the addition of an additional right wing for virtual testing in the V-model testify a strong focus on model-based approach and virtual, hybrid or physical testing. Comparable to Figure 2, in this V-model in Figure 4, both the "V" through the development process as well as the overall life cycle is shown.

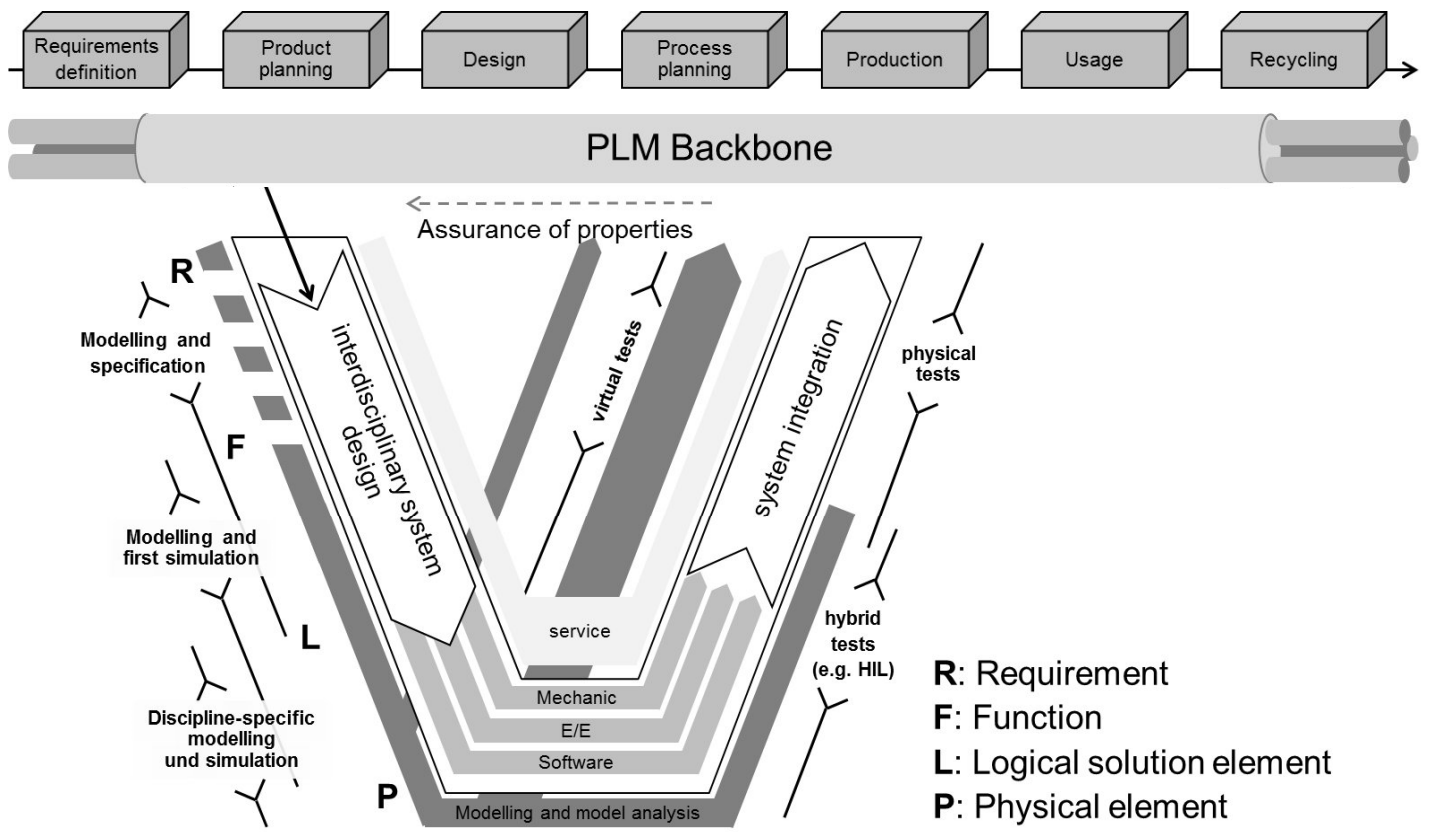

Figure 4. Extended V-model for model based systems engineering (Eigner et al., 2012) 
Bender's 2004 model also divides system development into hierarchical levels (Bender, 2005). It is noticeable here that the separation of the different domains does not take place at the top of the model, but already at the level of the subsystems. In addition, this V-model does not use any additional embracing to represent modelling and model analysis. This can be found in the description and of the individual sections. The model does not suggest an in or out track, and ultimately does not suggest a product life cycle.

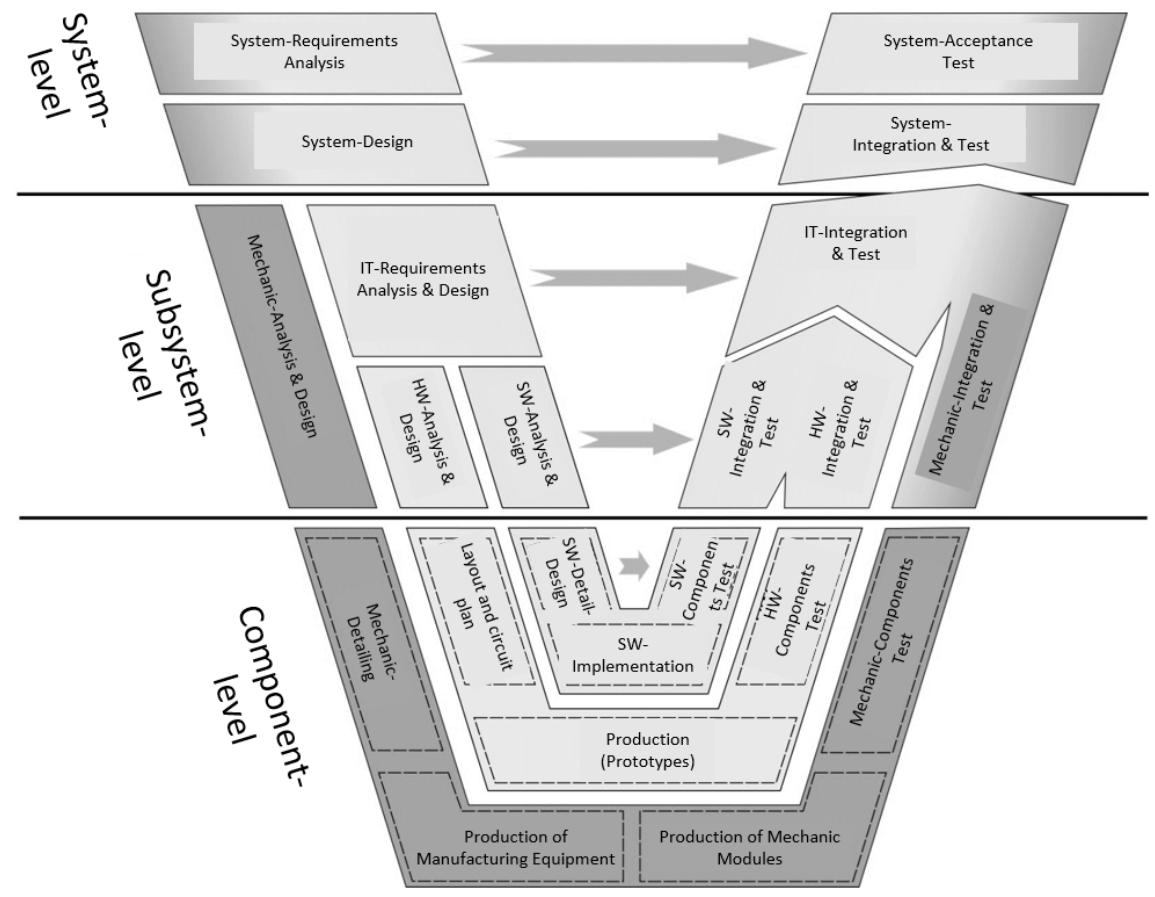

Figure 5. V-model by Bender 2005, translated from Bender (2005)

The V-model of INCOSE is illustrated as a sequential method used to visualize various key areas for SE focus, particularly during the concept and development stages. The "V" highlights the need for continuous validation with the stakeholders, the need to define verification plans during requirements development, and the importance of continuous risk and opportunity assessment (Walden et al., 2015).

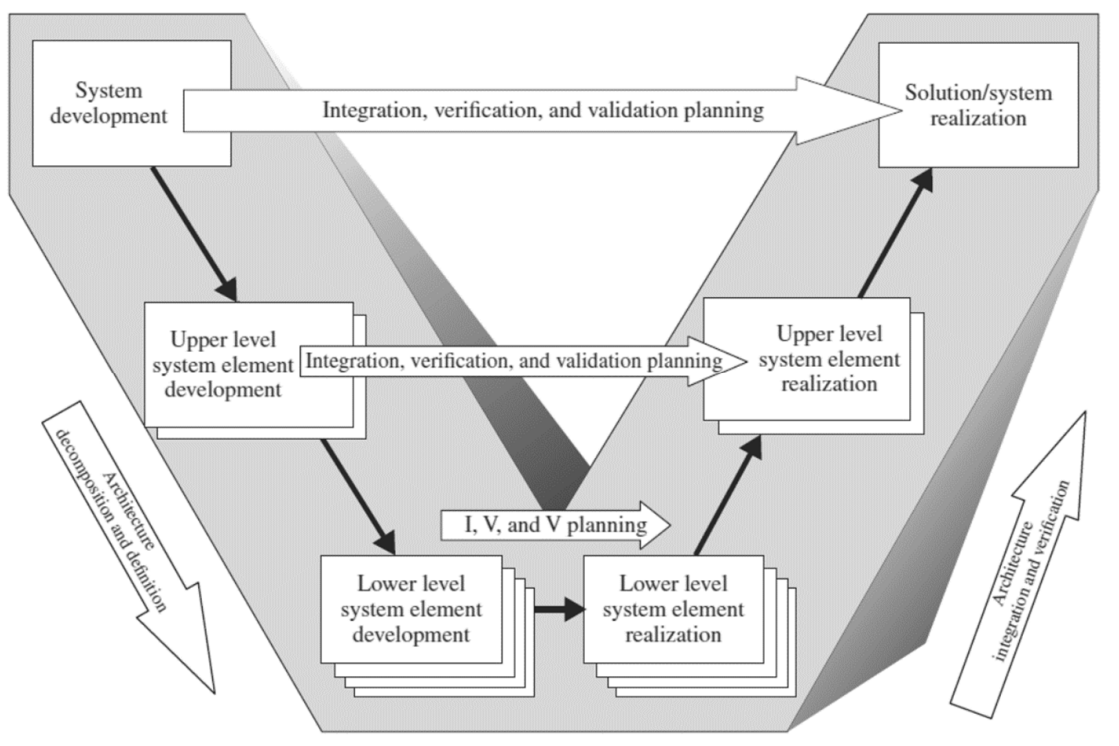

Figure 6. International Council on System Engineering (INCOSE) V-model (Walden et al., 2015) 
The following Table 1 summarizes the characteristic properties of the different V-models. Crucial for the evaluation is the impression conveyed by the graphics, the terminology used within the V-model and the content of the descriptive texts. The evaluation was carried out from scientific methodical perspective as well as industrial application perspective acquired in three different branches of industry.

Table 1. Overview of $V$-models by characteristic properties

\begin{tabular}{|c|c|c|c|c|c|c|c|}
\hline \# & $\begin{array}{c}\text { Characteristic } \\
\text { properties }\end{array}$ & $\begin{array}{l}\text { VDI 2206: } \\
2004\end{array}$ & US DoT & $\begin{array}{l}\text { Binz, } \\
\text { Watty }\end{array}$ & $\begin{array}{c}\text { Eigner, Gilz, } \\
\text { Zafirov }\end{array}$ & Bender & $\begin{array}{l}\text { INCOSE } \\
\text { SE4.0 }\end{array}$ \\
\hline 1 & $\begin{array}{c}\text { Decomposition } \\
\text { into System } \\
\text { levels }\end{array}$ & $\begin{array}{c}\text { Not } \\
\text { illustrated }\end{array}$ & $\begin{array}{l}\text { Yes, by } \\
\text { wording }\end{array}$ & $\begin{array}{l}\text { Not } \\
\text { illustrated }\end{array}$ & Not illustrated & $\begin{array}{l}\text { Yes, three } \\
\text { levels }\end{array}$ & $\begin{array}{l}\text { Yes, three } \\
\text { levels }\end{array}$ \\
\hline 2 & $\begin{array}{c}\text { Integration of } \\
\text { model-based } \\
\text { development } \\
\text { approach } \\
\end{array}$ & Yes, partly & No & Yes, partly & $\begin{array}{c}\text { Yes, plus } \\
\text { virtual tests }\end{array}$ & No & No \\
\hline 3 & $\begin{array}{l}\text { Provide status } \\
\text { revision }\end{array}$ & No & $\begin{array}{l}\text { Yes, decision } \\
\text { gates }\end{array}$ & No & No & No & $\begin{array}{c}\text { Not } \\
\text { illustrated }\end{array}$ \\
\hline 4 & $\begin{array}{c}\text { Life cycle } \\
\text { representation }\end{array}$ & No & Yes & Yes & Yes, backbone & No & No \\
\hline 5 & $\begin{array}{l}\text { Focused fields of } \\
\text { application }\end{array}$ & $\begin{array}{c}\text { Mechatronic } \\
\text { systems }\end{array}$ & $\begin{array}{l}\text { Infra-structure } \\
\text { systems }\end{array}$ & $\begin{array}{l}\text { Micro- } \\
\text { systems } \\
\text { tech- } \\
\text { nologies }\end{array}$ & $\begin{array}{l}\text { Model-based } \\
\text { Systems } \\
\text { Engineering } \\
\text { (MBSE) }\end{array}$ & $\begin{array}{l}\text { Embedded } \\
\text { Systems }\end{array}$ & $\begin{array}{c}\text { Systems } \\
\text { Engineering }\end{array}$ \\
\hline 6 & $\begin{array}{l}\text { Sequential or } \\
\text { iterative } \\
\text { approach }\end{array}$ & $\begin{array}{l}\text { Hints for } \\
\text { iterations }\end{array}$ & $\begin{array}{c}\text { Sequential, } \\
\text { straight forward } \\
\text { process }\end{array}$ & Iterative & Iterative & Iterative & $\begin{array}{c}\text { Sequential, } \\
\text { straight } \\
\text { forward } \\
\text { process }\end{array}$ \\
\hline 7 & $\begin{array}{l}\text { Adaptability to } \\
\text { maturity levels }\end{array}$ & Yes & $\begin{array}{l}\text { No, just for } \\
\text { large and } \\
\text { complex } \\
\text { infrastructure } \\
\text { projects }\end{array}$ & Yes & Yes & Yes & Yes \\
\hline 8 & Tutorial quality & $\begin{array}{l}\text { Wording } \\
\text { partly } \\
\text { unclear }\end{array}$ & $\begin{array}{l}\text { Many } \\
\text { sequential steps } \\
\text { are easy to } \\
\text { follow }\end{array}$ & $\begin{array}{l}\text { Procedia } \\
\text { and } \\
\text { wording } \\
\text { partly } \\
\text { unclear }\end{array}$ & $\begin{array}{l}\text { Procedia partly } \\
\text { unclear }\end{array}$ & $\begin{array}{l}\text { Procedia } \\
\text { partly } \\
\text { unclear }\end{array}$ & $\begin{array}{c}\text { General } \\
\text { explanation is } \\
\text { easy to } \\
\text { follow }\end{array}$ \\
\hline 9 & $\begin{array}{c}\text { Adaptability for } \\
\text { domains }\end{array}$ & $\begin{array}{l}\text { Yes, very } \\
\text { generic }\end{array}$ & $\begin{array}{l}\text { No special } \\
\text { focus }\end{array}$ & $\begin{array}{l}\text { Yes, very } \\
\text { generic }\end{array}$ & Yes & $\begin{array}{l}\text { No, explicit } \\
\text { description }\end{array}$ & $\begin{array}{l}\text { Yes, very } \\
\text { generic }\end{array}$ \\
\hline 10 & $\begin{array}{l}\text { Consideration of } \\
\text { Requirements } \\
\text { Engineering }\end{array}$ & $\begin{array}{c}\text { Described as } \\
\text { an input }\end{array}$ & $\begin{array}{l}\text { Partly for } \\
\text { definition }\end{array}$ & $\begin{array}{l}\text { Described } \\
\text { as an input }\end{array}$ & $\begin{array}{c}\text { Described as } \\
\text { first level of } \\
\text { development } \\
\text { (RFLP) }\end{array}$ & $\begin{array}{l}\text { Partly for } \\
\text { definition }\end{array}$ & $\begin{array}{c}\text { No, } \\
\text { schematic } \\
\text { model }\end{array}$ \\
\hline 11 & $\begin{array}{c}\text { Verification and } \\
\text { validation }\end{array}$ & Right to left & Left to right & $\begin{array}{l}\text { Right to } \\
\text { left }\end{array}$ & Right to left & $\begin{array}{l}\text { Left to } \\
\text { right }\end{array}$ & Left to right \\
\hline
\end{tabular}

\section{Resulting call for action}

The illustrated models and the derived Table 1 show the different emphases of the V-model variants. It is not crucial to integrate all focal points into one new model, but rather to observe the important innovations and changes in comparison to the previous VDI 2206 guideline.

The mentioned characteristic properties span a wide field of evaluation. The structured rating has been performed qualitatively and comparably in the above Table 1 . The derivation of the characteristic properties and the rating are based on the specific industrial experience and scientific knowledge of the three authors. Further, the results are validated by experts' discussion within the technical committee VDI GMA 4.10. Moreover, all results refer to the V-model of the current guideline 2206:2004. As the V- 
models that emerged over time reflect needs in the practical application of the V-model, these changes give an excellent indicator for necessary improvements. As these improvements have to be considered in a revision, it is reasonable to derive actions from the observed needs. Therefore, Table 2 aggregates the characteristic properties into five major categories of improvements of the V-model. The relevant characteristic properties that are basis for the call for action's category are collected in the second column.

Table 2. Derivation of the evaluation criteria with regard to the call for action

\begin{tabular}{|l|c|}
\hline \multicolumn{1}{|c|}{ Call for action } & Relevant characteristic properties \\
\hline 4.1 Continuous requirements elicitation and management & $4,6,10,11$ \\
\hline 4.2 Model-based design approach & 2,6 \\
\hline $\begin{array}{l}\text { 4.3 Holistic approach for architecture and domain-specific detailing } \\
\text { and implementation }\end{array}$ & $1,5,7,9$ \\
\hline 4.4 In-process status revision & $3,4,7,8,10,11$ \\
\hline 4.5 Impulses for enabling digital business models & $2,4,6$ \\
\hline
\end{tabular}

\subsection{Continuous requirements elicitation and management}

The aim of continuous requirements elicitation and management is to cover all requirements engineering activities during the development process (Gräßler et al., 2016). Requirements should not be seen and illustrated as just an input of the V-model (Gräßler et al., 2016; Graessler, 2017). Requirements elicitation and management, as for example pointed out in different Systems Engineering Handbooks (United States Department of Defense, 2001; National Aeronautics and Space Administration, 2007; U.S. Department of Transportation, 2009; Walden et al., 2015) are important during the whole development process. Just a small number of requirements can be seen as an input for example from the customer. Most of the requirements, especially implicit needs of the customer, have to be elaborated in early development phases. Later on, additionally to structuring and developing the target product based on the collected requirements, the meaning and consequences of changes are focus of requirements management. A requirements list is not a static document. It has to be updated, changed and customized during the whole development process (Pohl and Rupp, 2015; Gräßler and Hentze, 2017). Furthermore, in addition to the definition of requirements, the implementation of testability has to be defined in early stages at the left side of the V-model.

\subsection{Model-based design approach}

On account of the complex structure and interdisciplinary characters, not only the individual systems and related components, but also the other parts in the V-model including requirements should be modelled (Holt et al., 2015). This is underlined by the fact, that tools like DOORS, Magic Draw or SysML are used to describe requirements and their structure in models (Weilkiens, 2014; Gräßler and Hentze, 2017). On the one hand, models provide clear structures to deal with the complexity. On the other hand, models are a simple understandable and standardized language for all involved engineers and managers (Pohl et al., 2012; Gräßler et al., 2016; Eigner et al., 2017).

Additionally, most mechatronic product development processes are faced with cost and time pressure. As physical and mathematical models of mechanical systems including hydraulics, electrical and electronic components as well as software structures allow simulation and prediction of behaviour and properties of mechatronic systems in early phases, they are nowadays standard to accelerate the development process. Modelling is not only a purpose to increase efficiency of product development, but becomes a companion of the product over the whole life cycle. From this idea, the concept of the digital twin was created, which also plays a relevant role for model-based digital business models (see Section 4.5).

\subsection{Holistic approach for architecture and domain-specific detailing and implementation}

The sole mention of the system design in the phase of decomposition of the V-model does not reflect complete activities: The target system or target product is composed into different subsystems and elements. In the first step, a system architecture is developed as shown in Figure 7. This forms the framework for the different subsystems and elements. As a result, in an iterative reconciliation process with the system architecture, the subsystems and elements are designed (Walden et al., 2015). 
Particularly in system architecture, the phase in which interfaces are defined, an interdisciplinary cooperation is necessary. The domains that later determine the design of the systems have to be able to set the requirements and constraints already during the interface definition. The better this collaboration happens and the clearer interfaces are defined, the less iteration with design process is necessary.

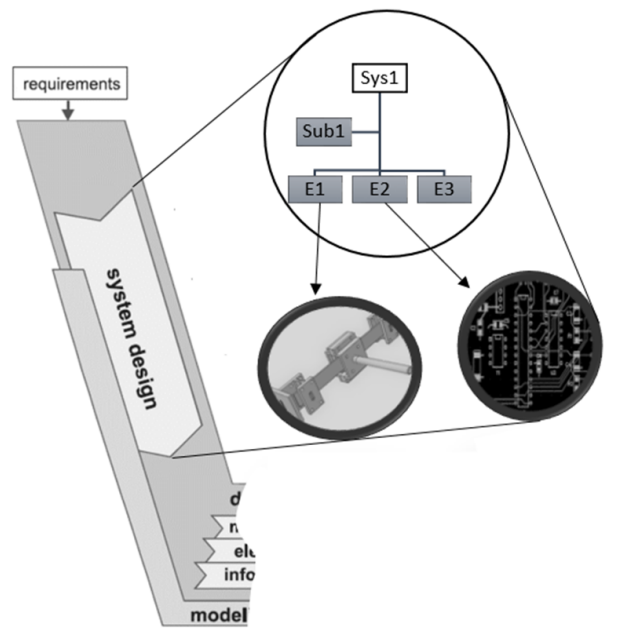

Figure 7. Integration of system architecture into the system design process, based on VDI (2004)

\subsection{In-process status revision}

Various approaches of project management and applied development methodologies in an industrial context integrate reviews of the contents or the procedural approach (Cooper, 2002, 2008, 2017). This points of control can also be adapted to a general model of product development. It should not be the content of the development progress to be reviewed in the check points, but the development method and general organizational and project management topics and relationships are examined. The control points may be less than a milestone or gate, as in project management, but rather should help to make the development process more efficient and effective. Points of control can be enhanced by checklists, which describe the tailored necessities at that point of time in the development process. Unlike the DoT V-model from Figure 2, the number in a single pass through the V-model should not exceed six. To many status revisions lead to straight forward step-by-step process, which does not represent the iterative reality in development processes. Figure 8 shows two possible integrations of control points into the Vmodel. On the one hand according to the system design, all interfaces and the conditions for the domainspecific design must be established. On the other hand, at the end of the current development cycle, a product arrives the end of a development cycle. End of a development cycle can mean a development iteration, a transfer to another business unit or the handover to a customer.

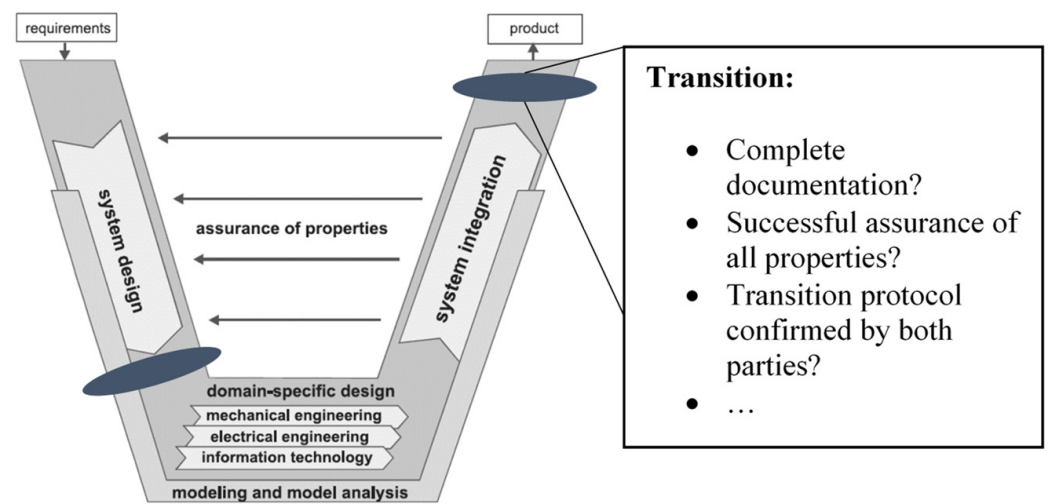

Figure 8. Exemplary integration of status revision, based on VDI (2004) 


\subsection{Impulses for enabling digital business models}

The enabling of digital business models can be divided into two aspects: First, because engineers as system or element developers work close to modern technologies, they collect lots of knowledge about digital technologies and their opportunities. Development methodologies have to use this source of knowledge not only for the development, but also for creating new ideas for business models. Including that interconnections is essential for life cycle engineering.

Second aspect of the representation of digital business models in development processes is the possibility of a digital product, for example of a digital twin (Bundesministerium für Wirtschaft und Energie, 2015; du Montcel, 2016; Eigner et al., 2017). These products for example could be sold as subsystems for virtual testing to OEM. Thus, the target product changes to a purely digital product. This changes the involvement of different disciplines and life cycle restrictions for the product. To transfer this idea to the development process, there will be impacts for the architecture of the systems. The external interfaces of the systems have to be described with the aim of realizing digital business models. Application in the field of industry are predictive maintenance and online monitoring of airplane turbines (Milligan et al., 2017) as presented by Rolls Royce and Microsoft (Wocher, 2016) or usagebased payments. Here, standards and general guidelines are still under development which is a challenge for the development of mechatronic products of the future.

\section{Summary and outlook}

The compared V-models of interdisciplinary development methodology literature and Systems Engineering (SE) show different aspects and focus on specific applications. Driven by changes in technology and market needs, different applications, products and approaches were introduced over the years since 2004. Within this article, an evaluation based on a set of selected characteristic properties shows that five topics have emerged which should be incorporated into the new version of the V-model. The desired aspects can be achieved in part by references, for example to the product life cycle model of the planned VDI 2000 guideline, and partly by additions and changes within the V-model. A clear statement of definitions is crucial, especially facing the different engineering disciplines involved. Examples have to be provided that focus multiple aspects and examples of mechatronic engineering. These modifications are mission of the technical committee VDI GMA 4.10 "Interdisciplinary Product Creation" who also aim at an interconnecting the V-model with a product life cycle model in the future VDI 2000. Clearly, both guidelines have to reference each other to avoid redundancies and explain the holistic view.

\section{Acknowledgement}

The previous work of the VDI technical committee VDI GMA FA 4.10 will be presented, discussed and validated during the workshop "Validate the V-Model for New VDI 2206" at the DESIGN 2018 Conference at Dubrovnik. The results of this paper will be used as input to the development of the new V-model.

\section{References}

Bender, K. (2005), Embedded Systems - qualitätsorientierte Entwicklung, Springer-Verlag, Berlin,Heidelberg. https://doi.org/10.1007/b138984

Bröhl, A.-P. (1995), Das V-Modell: Der Standard für die Softwareentwicklung mit Praxisleitfaden, Software Anwendungsentwicklung - Informationssysteme, 2nd ed., Oldenbourg, München.

Bundesministerium für Wirtschaft und Energie (2015), Industrie 4.0 und Digitale Wirtschaft: Impulse für Wachstum, Beschäftigung und Innovation, PRpetuum GmbH, Munich.

Cooper, R.G. (2002), Top oder Flop in der Produktentwicklung: Erfolgsstrategien; von der Idee zum Launch, 1st ed., Wiley-VCH Verlag GmbH \& Co., Weinheim.

Cooper, R.G. (2008), "Perspective. The Stage-Gate ${ }^{\circledR}$ Idea-to-Launch Process-Update, What's New, and NexGen Systems", Journal of Product Innovation Management, Vol. 25 No. 3, pp. $213-232$. https://doi.org/10.1111/j.1540-5885.2008.00296.x

Cooper, R.G. (2017), Winning at new products: Creating value through innovation, 5th ed., Basic Books, New York.

du Montcel, B.T. (2016), "When Digitalization drives supply networks reconfiguration”, Proceedings of the R\&D Management Conference, Cambridge, UK, July 3-6, 2016. 
Ehrlenspiel, K. and Meerkamm, H. (2013), Integrierte Produktentwicklung: Denkabläufe, Methodeneinsatz, Zusammenarbeit, 5th ed., Hanser, München. https://doi.org/10.3139/9783446436275

Eigner, M., Gilz, T. and Zafirov, R. (2012), Interdisziplinäre Produktentwicklung - Modellbasiertes Systems Engineering. [online] PLM portal. Available at: https://www.plmportal.org/de/forschungdetail/interdisziplinaere-produktentwicklung-modellbasiertes-systems-engineering.html (accessed 12.03.2018).

Eigner, M., Koch, W. and Muggeo, C. (2017), Modellbasierter Entwicklungsprozess cybertronischer Systeme: Der PLM-unterstützte Referenzentwicklungsprozess für Produkte und Produktionssysteme, Springer Vieweg, Berlin, Heidelberg. https://doi.org/10.1007/978-3-662-55124-0

Gausemeier, J. and Moehringer, S. (2003), "New Guideline VDI 2206 - a Flexible Procedure Model for The Design of Mechatronic Systems", Proceedings of ICED'03 / the 14th International Conference on Engineering Design, Stockholm, Sweden, August 19-21, 2003, The Design Society, Glasgow.

Graessler, I. (2017), “A New V-Model for Interdisciplinary Product Engineering”, Proceedings of the 59th Ilmenau Scientific Colloquium, Ilmenau, Germany, September 11-15, 2017, ilmedia, Ilmenau.

Gräßler, I. and Hentze, J. (2015), "A V-model based comparison of Systems Engineering approaches", Proceedings of ECEC 2015 / the $22^{\text {nd }}$ European Concurrent Engineering Conference, Lisbon, Portugal, April 27-29, 2015, EUROSIS-ETI, Lisbon, pp. 80-86.

Gräßler, I. and Hentze, J. (2017), "Structuring and Describing Requirements in a Flexible Mesh for Development of Smart Interdisciplinary Systems", Proceedings of SMART17 / the 8th ECCOMAS Thematic Conference on Smart Structures and Materials, Madrid, Spain, June 5-8, 2017, CIMNE, pp. 1622-1631.

Gräßler, I., Hentze, J. and Yang, X. (2016), "Eleven Potentials for Mechatronic V-Model", Proceedings of the 6th International Conference on Production Engineering and Management, Lemgo, Germany, September 29-30, 2016. pp. 257-268.

Holt, J., Perry, S., Payne, R., Bryans, J., Hallerstede, S. and Hansen, F.O. (2015), “A Model-Based Approach for Requirements Engineering for Systems of Systems”, IEEE Systems Journal, Vol. 9 No. 1, pp. $252-262$. https://doi.org/10.1109/JSYST.2014.2312051

Milligan, W.J., Poli, G. and Harrison, D.K. (2017), "The Integration of an API619 Screw Compressor Package into the Industrial Internet of Things", Proceedings of $10^{\text {th }}$ International Conference on Compressors and their Systems, London, UK, September 11-13, 2017, IOPscience. https://doi.org/10.1088/1757-899X/232/1/012088

National Aeronautics and Space Administration (2007), Systems Engineering Handbook, Revision 1, NASA, Washington D.C.

Pohl, K. and Rupp, C. (2015), Requirements engineering fundamentals, 2nd ed., Rocky Nook, Santa Barbara, CA.

Pohl, K., Hönninger, H., Achatz, R. and Broy, M. (2012), Model-Based Engineering of Embedded Systems: The SPES 2020 Methodology, Springer, Berlin, Heidelberg. https://doi.org/10.1007/978-3-642-34614-9

U.S. Department of Transportation (2009), Systems Engineering Guidebook for Intelligent Transportation Systems: Version 3.0, U.S. Department of Transportation, Washington D.C.

United States Department of Defense (2001), Systems Engineering Fundamentals, Fort Belvour, Virginia.

VDI (2004), VDI 2206 - Design methodology for mechatronic systems, The Association of German Engineers (VDI), Düsseldorf.

Walden, D.D., Roedler, G.J., Forsberg, K., Hamelin, R.D. and Shortell, T.M. (2015), Systems engineering handbook: A guide for system life cycle processes and activities, 4th ed., Wiley.

Watty, R. (2006), Methodology for the development of MEMS products, PhD thesis, Universität Stuttgart.

Weilkiens, T. (2014), Systems Engineering mit SysML/UML: Modellierung, Analyse, Design, 3rd ed., dpunkt.verlang, Heidelberg, Neckar.

Wocher, M. (2016), Die Verschmelzung der Welten. Geschäftsmodell Datenanalyse. [online] Handelsblatt. Available at: http:/www.handelsblatt.com/technik/hannovermesse/geschaeftsmodell-datenanalyse-dieverschmelzung-der-welten/13517718.html

Julian Hentze, Research Assistant

Paderborn University, Heinz Nixdorf Institut - Product Creation

Fuerstenallee 11, 33102 Paderborn, Germany

Email: julian.hentze@hni.upb.de 